Full-length article

\title{
Evaluation of drug-muscarinic receptor affinities using cell membrane chro- matography and radioligand binding assay in guinea pig jejunum membrane
}

\author{
Bing-xiang $\mathrm{YUAN}^{1}$, Jin $\mathrm{HOU}$, Lang-chong $\mathrm{HE}^{2}$, Guang-de $\mathrm{YANG}^{2}$ \\ Department of Pharmacology; ${ }^{1}$ Pharmacy College, Xi-an Jiaotong University, Xi-an 710061, China
}

\section{Key words}

chromatography; cell membrane; muscarinic receptors; radioligand assay; jejunum

\footnotetext{
${ }^{1}$ Corresponding to Prof. Bing-xiang YUAN. Phn 86-29-8265-5165.

E-mail ybx@mail.xjtu.edu.cn
}

Received 2004-02-03

Accepted 2004-06-22

doi: $10.1111 / \mathrm{j} .1745-7254.2005 .00015 . \mathrm{x}$

\begin{abstract}
Aim: To study if cell membrane chromatography (CMC) could reflect drug-receptor interaction and evaluate the affinity and competitive binding to muscarinic acetylcholine receptor (mAChR). Methods: The cell membrane stationary phase (CMSP) was prepared by immobilizing guinea pig jejunum cell membrane on the surface of a silica carrier, and was used for the rapid on-line chromatographic evaluation of ligand binding affinities to $\mathrm{mAChR}$. The affinity to $\mathrm{mAChR}$ was also evaluated from radioligand binding assays (RBA) using the same jejunum membrane preparation. Results: The capacity factor $\left(k^{\prime}\right)$ profiles in guinea pig jejunum CMSP were: (-)QNB (15.4)>(+)QNB (11.5)>atropine (5.35)>pirenzepine (5.26) $>4$-DAMP (4.45)>AF-DX116 (4.18)>pilocarpine (3.93)>acetylcholine (1.31). These results compared with the affinity rank orders obtained from radioligand binding assays indicated that there was a positive correlation $\left(r^{2}=\right.$ $0.8525, P<0.0001)$ between both data sets. Conclusion: The CMC method can be used to evaluate drug-receptor affinities for drug candidates.
\end{abstract}

\section{Introduction}

Radioligand binding assay (RBA) is a traditional method in studying drug-receptor interactions. Although radioligand binding assay has some advantages, such as high sensitivity, it results in radioactive pollution and needs special separation methods. Cell membrane chromatography (CMC), a new bio-affinity chromatography technique originated by $\mathrm{Dr}$ He in $1999^{[1]}$, can be used to observe the binding of a drug and target (including receptor), simply and conveniently.

Previous experiments have indicated that the receptors immobilizing on the cell membrane stationary phase (CMSP) remain bio-active ${ }^{[2,3]}$. However, it is necessary to study whether this approach can be adopted to evaluate drug-receptor interaction and reflect affinity and competitive binding, although CMC has previously been used to screen for drug and herb candidates ${ }^{[4,5]}$.

\section{Materials and methods}

Animals and drugs Adult guinea pigs (350-400 g) of either sex were provided by the Experimental Animal Cen- ter of Xi-an Jiaotong University, China. Atropine, pirenzepine, nicotine, pilocarpine, 4-diphenylacetoxy- $N$-methylpiperidine (4-DAMP), 11-2\{[2-[(diethylamino) methyl $]-1-$ piperidinyl]acetyl $\}-5,11$-dihydro-6H-pyrido-(2,3-b) $(1,4)$ benzodiazepine-6-one (AF-DX116) were purchased from Sigma Co. Acetylcholine (ACh) was purchased from Shanghai Medical Co. (-)QNB and (+)QNB was provided by RBI Co. Tritiated quinuclidinyl benzilate $\left(\left[{ }^{3} \mathrm{H}\right] \mathrm{QNB}\right)$ was purchased from Amersham Radio-Chemical Center with a radioactivity of $1813 \mathrm{TBq} / \mathrm{mol}$.

Membrane preparation of jejunum vertical muscle Guinea pigs were killed and the jejunum was removed immediately. The intestine was washed thoroughly in normal saline and the canal was rubbed vertically using a tampon; then the vertical muscle was cut into small pieces and added to ice-cold PBS buffer. The tissue suspension was homogenized under a cradle at $4{ }^{\circ} \mathrm{C}$ (twice, for $1 \mathrm{~min}$ each). The crude homogenate was centrifuged at $600 \times \mathrm{g}$ for $10 \mathrm{~min}$ to remove cellular debris. The supernatant was filtered through cheesecloth and then centrifuged for $40 \mathrm{~min}$ at $20000 \times g$. The buff-colored layer around the pellet was gen- 
tly resuspended in the above buffer and centrifuged as previously explained $^{[6,7]}$.

Radioligand-receptor binding assay $\left[{ }^{3} \mathrm{H}\right] \mathrm{QNB}$ with a radioactivity of $37 \mathrm{PBq} / \mathrm{L}$, was used as a ligand to label muscarinic binding sites in membrane prepared from guinea pig jejunum. Aliquots $(200 \mu \mathrm{L})$ of the membrane suspensions were incubated with $0.5 \mathrm{nmol} / \mathrm{L}\left[{ }^{3} \mathrm{H}\right] \mathrm{QNB}$ in $50 \mathrm{mmol} / \mathrm{L}$ PBS buffer for $40 \mathrm{~min}$ at $37^{\circ} \mathrm{C}$. Non-specific binding was estimated from the duplicate tube containing $0.01 \mathrm{mmol} / \mathrm{L}$ atropine. The drug-receptor affinities were estimated by $\mathrm{p} K_{\mathrm{D}}$.

$$
\mathrm{p} K_{\mathrm{D}}=-\lg K_{\mathrm{D}}
$$

Chromatography experiment With a known concentration-competitive ligand added in the mobile phase, the combination between ligand and receptor protein was saturated on the CMSP. At the key time, the solute eluted from CMSP was increased drastically, thus forming a characteristic curve breakage. Conceptually, there are mean breakage sites in the curve, which only relate to the equilibrium dissociation constant or relationship between drug concentration and the number of receptors on the CMSP column. Moreover, in the solute disassociation process, the result can be analyzed by Scatchard-Plot method:

$$
\frac{1}{M_{\text {Lapp }}}=\frac{1}{K_{\mathrm{a}} M_{\mathrm{L}}[D]}+\frac{1}{M_{\mathrm{L}}}
$$

where $M_{\text {Lapp }}$ is the mole number of drug at mean breakage site, $[D]$ is drug concentration, $K_{\mathrm{a}}$ is association constant of the drug, and $M_{\mathrm{L}}$ is the total number of combination site of receptor protein on the column. If non-specific combination can not be neglected, the following formula is obtained: where $V$ is the retention volume of drug, $[P]$ is the concentration of receptor combination site, $V_{\min }$ is retention volume

$$
\frac{1}{V_{\max }-V_{\mathrm{i}}}=\frac{1+[D] K_{\mathrm{a}}}{V_{\min }[P] K_{\mathrm{a} X}}+\frac{\left(1+[D] K_{\mathrm{a}}\right)^{2}}{V_{\min }[P] K_{\mathrm{a} X}} \cdot \frac{1}{[X]}
$$

of drug when the specific interaction is completely inhibited, and $V_{\max }$ is obtained from the formula. [X] is the concentration of additive, which completes the same site of $D . V_{\max }$ is the retention volume of $[D]$ at low concentration $\left([D]<<1 / K_{\mathrm{a}}\right.$, $\left.V=V_{\max }\right)$ and $V_{\mathrm{x}}$ is the retention volume of $D$ when competitive interaction exists. The value of $V_{\min }$ can be determined by regressing $1 /\left(V_{\max }-V\right)$ versus $1 /[D]$ extrapolating to infinite $\left(V_{\mathrm{I}}=V_{\min }\right)$.

$$
\frac{1}{V-V_{\min }}=\frac{1}{V_{\min }[P] K_{\mathrm{a}}}+\frac{1}{V_{\min }[P]} \cdot[D]
$$

In the chromatographic system, the capacity factor $\left(k^{\prime}\right)$ can reflect the mole fraction ratio of stationary and mobile phase at equilibrium. The silica surface is completely coated by the cell membrane in CMSP, so $k^{\prime}$ is characteristic of the action between the drug and the cell membrane, which means, the larger $k^{\prime}$ showes a stronger affinity for the same chromatographic condition.

CMSP was prepared by immobilizing above guinea pig jejunum cell membrane on the surface of a silica carrier, provided by the Pharmacy Center of Xi' an Jiaotong University ${ }^{[4]}$, China. CMSP was packed in the chromatography column $(50 \mathrm{~mm} \times 2 \mathrm{~mm}$, id, $7 \mu \mathrm{m})$ and equilibrated with at least $15 \mathrm{~mL}$ PBS buffer $50 \mathrm{mmol} / \mathrm{L}$ before runing different ligands. The mobile phase was pumped through the column at a flow rate of $0.5 \mathrm{~mL} / \mathrm{min}$ at $37^{\circ} \mathrm{C}$. Before different ligands were injected, the column was equilibrated with at least 15 $\mathrm{mLPBS}$ mobile phase $50 \mathrm{mmol} / \mathrm{L}$. When $0.01 \mathrm{mmol} / \mathrm{L}$ atropine was added to the PBS buffer, the column was equilibrated again with this mobile phase before injection. Capacity factors were calculated from:

$$
k^{\prime}=\left(t_{\mathrm{R}}-t_{0}\right) / t_{0}
$$

where $t_{\mathrm{R}}$ is retention time of ligands, and $t_{0}$ is retention time of solvent. Ligand retention time was detected by ultraviolet on-line in 190-230 nm wavelength.

Statistical analysis Values were presented as mean \pm SD. Correlation between both data sets were analyzed by linear regression using GraphPad Prism 2.01.

\section{Results}

Radioligand-receptor binding experiment Competition for $\left[{ }^{3} \mathrm{H}\right] \mathrm{QNB}$ binding by unlabelled ligands showed different affinity in guinea pig jejunum membrane. None of the Hill coefficient was significantly different from unity. The rank orders of potency $\left(\mathrm{p} K_{\mathrm{d}}\right)$ were $(-) \mathrm{QNB}>(+) \mathrm{QNB}>$ atropine $>4$-DAMP $>$ AF-DX116 $>$ pirenzepine $>$ pilocarpine $>$ ACh. Nicotine had little affinity with muscarinic receptor (Table 1).

Cell membrane chromatography experiment In the CMC experiment, capacity factors $\left(k^{\prime}\right)$ were used to describe the ligand-CMSP affinity. The bigger the capacity factor, the stronger the affinity will be. The sequence of the relative affinities of selected ligands were $(-) \mathrm{QNB}>(+) \mathrm{QNB}>$ atropine $>$ pirenzepine $>4-D A M P>A F-D X 116>$ pilocarpine $>$ $\mathrm{ACh}$, which were consistent with results calculated from radioligand binding assays, except for pirenzepine. Yet and nicotine had some capacity factor. When atropine was added in the mobile phase the capacity factor of (-)QNB, $(+)$ QNB, atropine, pirenzepine, 4-DAM, AF-DX116, pilocarpine and ACh could be reduced, while the capacity factor of nicotine could not be reduced (Table 2). 
Table 1. Binding parameters of different ligands in muscarinic receptor of guinea pig jejunum membrane detected by using $\left[{ }^{3} \mathrm{H}\right] \mathrm{QNB}$ displacement experiment.

\begin{tabular}{lcccc}
\hline Ligand & \multicolumn{4}{c}{$\mathrm{p} K_{\mathrm{D}}$} \\
& $\mathrm{x}_{1}$ & $\mathrm{x}_{2}$ & $\mathrm{x}_{3}$ & Mean $\pm \mathrm{SD}$ \\
\hline & & & & \\
$(-) \mathrm{QNB}$ & 8.72 & 8.66 & 8.84 & $8.74 \pm 0.09$ \\
(+)QNB & 7.23 & 7.12 & 7.21 & $7.19 \pm 0.06$ \\
Atropine & 7.05 & 6.60 & 6.75 & $6.80 \pm 0.23$ \\
4-DAMP & 6.38 & 6.18 & 6.30 & $6.29 \pm 0.10$ \\
AF-DX116 & 6.21 & 6.40 & 6.23 & $6.28 \pm 0.10$ \\
Pirenzepine & 5.67 & 6.05 & 6.03 & $5.92 \pm 0.21$ \\
Pilocarpine & 5.33 & 5.28 & 5.40 & $5.34 \pm 0.06$ \\
Ach & 5.07 & 4.70 & 4.86 & $5.25 \pm 0.17$ \\
Nicotine & 2.97 & 3.05 & 3.04 & $3.02 \pm 0.04$ \\
& & & & \\
\hline
\end{tabular}

QNB: quinuclidinyl benzilate; 4-DAMP: 4-diphenylacetoxy- $N$-methylpiperidine; AF-DX116: 11-2\{[2-[(diethylamino)methyl]-1-piperidinyl] acetyl $\}-5,11$-dihydro-6H-pyrido-(2,3-b)(1,4) benzodiazepine-6-one; ACh: acetylcholine. The guinea pig jejunum homogenates were incubated with $0.5 \mathrm{nmol} / \mathrm{L}\left[{ }^{3} \mathrm{H}\right] \mathrm{QNB}$ for $40 \mathrm{~min}$ at $37{ }^{\circ} \mathrm{C}$ in the presence of tested ligands.

\section{Discussion}

The results of the present study demonstrated that membrane preparation including $\mathrm{mACh}$ receptor could be immobilized on the stationary phase with retention of their binding activities. Different ligands had different capacity factors and the rank orders were consistent with results from radioligand binding assay except for pirenzepine. During the experiment, when atropine was added to the mobile phase the capacity factor of (-)QNB, (+)QNB, atropine, pirenze- pine, 4-DAMP, AF-DX116, pilocarpine, and ACh decreased. This indicated that those ligands could bind to $\mathrm{mACh}$ receptor on CMSP and the affinity could be inhibited in competitive displacement by atropine. The capacity factor of nicotine could not be decreased in competitive displace-ment, so the ligands have no competitive site with atropine. Therefore, we can infer that capacity factor can evaluate the affinity of ligand-mACh receptor and reflect the selectivity and specificity of drug-receptor interaction. While at present the equilibrium dissociation constant can not be calculated by CMC method directly, linear regression analysis showed that both the data sets correlated with $r^{2}=0.8525(n=24)$, $P<0.0001$ in PBS mobile phase, or with $r^{2}=0.8461 \quad(n=24)$, $P<0.0001$ in PBS mobile phase with $0.01 \mathrm{mmol} / \mathrm{L}$ atropine (Figure 1).

It was demonstrated that the CMC model could be used to observe binding of the drug and receptor on a dynamic condition, and the characters of drug-receptor interactions can be shown by chromatographic parameters of drugs on the CMC model. However, we noticed that affinity rank orders from different methods were not entirely consistent. In the CMC model, affinity of pirenzepine according to the $k^{\prime}$ value was relatively higher than the corresponding affinity determined using radioligand binding assay. Similar results about pirenzepine were observed in other study ${ }^{[8]}$. When atropine was added in the mobile phase, the affinity discrepancy was not eliminated. The source of the different affinity orders is not readily elucidatory. It would be likely to blame low sensitivity of the CMC model for the ligands, because most ligands of $\mathrm{mACh}$ receptor are at the margin of ultraviolet on-line in 190-230 nm wavelength, or outward of the range. It is necessary for us to improve the sensitivity of the

Table 2. Capacity factor $\left(k^{\prime}\right)$ of different ligands measured using cell membrane stationary phase in mobile phase of PBS and PBS with $0.01 \mathrm{mmol} / \mathrm{L}$ atropine.

\begin{tabular}{|c|c|c|c|c|c|c|c|c|}
\hline \multirow[t]{3}{*}{ Ligand } & \multicolumn{8}{|c|}{$k^{\prime}$} \\
\hline & \multicolumn{4}{|c|}{ PBS } & \multicolumn{4}{|c|}{ PBS with $0.01 \mathrm{mmol} / \mathrm{L}$ atropine } \\
\hline & $\mathrm{x}_{1}$ & $\mathrm{x}_{2}$ & $\mathrm{x}_{3}$ & Mean \pm SD & $\mathrm{x}_{1}$ & $\mathrm{x}_{2}$ & $\mathrm{x}_{3}$ & Mean \pm SD \\
\hline$(-) \mathrm{QNB}$ & 14.9 & 15.6 & 15.7 & $15.4 \pm 0.44$ & 11.7 & 12.2 & 10.7 & $11.5 \pm 0.76$ \\
\hline$(+) \mathrm{QNB}$ & 11.6 & 12.0 & 10.9 & $11.5 \pm 0.56$ & 8.24 & 8.89 & 8.11 & $8.41 \pm 0.42$ \\
\hline Atropine & 5.19 & 5.93 & 4.94 & $5.35 \pm 0.51$ & 4.03 & 4.47 & 4.13 & $4.21 \pm 0.23$ \\
\hline Pirenzepine & 5.12 & 5.40 & 5.25 & $5.25 \pm 0.14$ & 4.38 & 4.86 & 4.67 & $4.64 \pm 0.24$ \\
\hline 4-DAMP & 4.12 & 4.94 & 4.29 & $4.45 \pm 0.43$ & 3.85 & 3.29 & 3.36 & $3.50 \pm 0.31$ \\
\hline AF-DX116 & 4.44 & 3.97 & 4.12 & $4.18 \pm 0.24$ & 2.99 & 3.31 & 3.11 & $3.14 \pm 0.16$ \\
\hline Pilocarpine & 3.54 & 4.13 & 4.13 & $3.93 \pm 0.34$ & 3.02 & 3.30 & 3.08 & $3.13 \pm 0.15$ \\
\hline $\mathrm{ACh}$ & 1.14 & 1.43 & 1.37 & $1.31 \pm 0.15$ & 1.13 & 0.97 & 0.97 & $1.02 \pm 0.09$ \\
\hline Nicotine & 1.14 & 0.99 & 1.08 & $1.07 \pm 0.08$ & 1.03 & 1.20 & 1.08 & $1.10 \pm 0.09$ \\
\hline
\end{tabular}



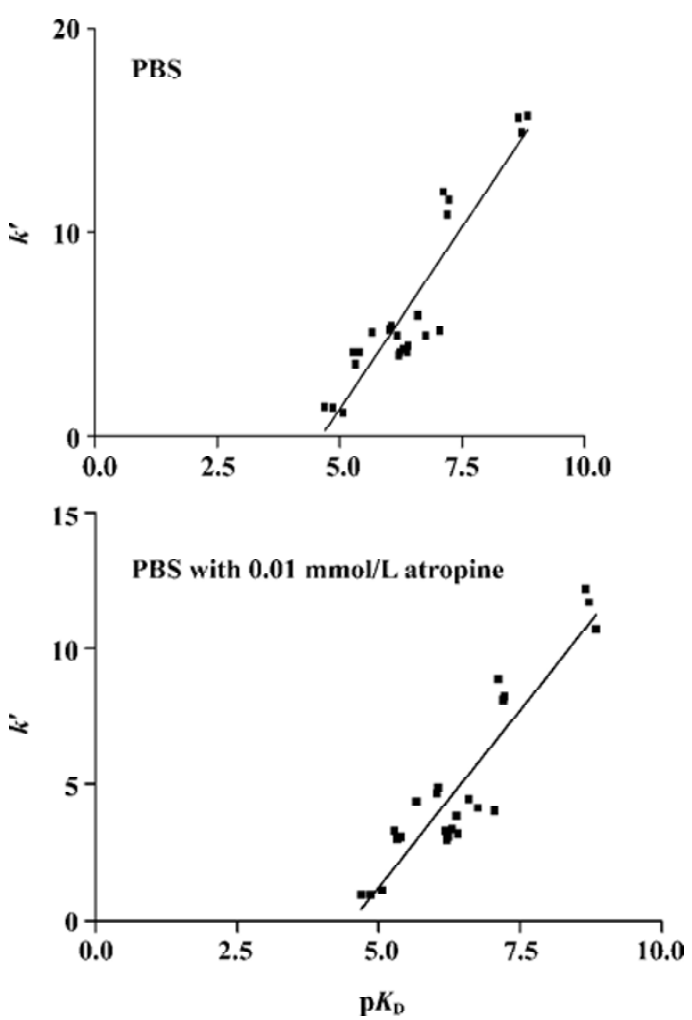

Figure 1. Relationship between capacity factor $\left(k^{\prime}\right)$ and negative logarithm of equilibrium dissociation constant $\left(\mathrm{p} K_{\mathrm{D}}\right)$. PBS: $Y=3.754 X$ $16.55, r^{2}=0.8525, n=24, P<0.0001$; PBS with $0.01 \mathrm{mmol} / \mathrm{L}$ atropine: $Y=2.607 X-11.81, r^{2}=0.8461, P<0.0001$.

CMC model by using other detectors, like a fluorescence detector or laser detector. Before further study, CMC can be used to screen for drug candidates and accuracy can be validated by traditional radioligand binding assay. The development of CMC could offer a number of unique advantages. The receptors can be placed in a stabilized format and could therefore be reused over a long period of time. Thus, it might be possible to perform multiple experiments with hard-to-obtain receptors using an immobilized format.

\section{References}

1 He LC, Yang GD, Geng XD. Enzymatic activity and chromatographic characteristics of the cell membrane immobilized on silica surface. Chin Sci Bull 1999; 44: 826-31.

2 He LC, Wang SC, Geng XD. Coating and fusing cell membranes onto a silica surface and their chromatographic characteristics. Chromatographia 2001; 54: 71-6.

3 He LC, Geng XD. Cell membrane chromatography-a new technique in studying drug-receptor interaction. In: Zhou TH, Liu GQ, editors. Biomedical Chromatography Progress. Beijing: Chemical Industry Publishing House; 1996. p 8-10.

4 He LC, Yang GD, Wang SC. Evaluation of drug-calcium channels reaction using cell membrane chromatography. Chin J Pharmacol Toxicol 1998; 14: 959-61.

5 Zhao HR, Yang GD, He LC, Yang YJ. Screening effective components of angelica using cell membrane chromatography. Chin Pharm J 2000; 35: 13-5.

6 Michael ID, Robert PS. Ligand interactions with membrane-bound porcine atrial muscarinic receptors. Biochemistry 1980; 19: 3407-13.

7 Nedoma J, Slavikova J, Tucek S. Muscarinic acetylcholine receptors in the heart of rats before and after birth. Pflugers Arch 1986; 406: 45-50.

8 Hou J, Yuan BX, He LC, Yang GD, Mi M. Evaluation of drug-muscarinic receptor affinities by using cell membrane chromatography. Chin J Pharmacol Toxicol 2003; 17: 70-3. 